\title{
Increased Customer Loyalty in the Retail Banking Sector and Impact on the Bank's Financial Performance
}

\author{
Assel Iskhakova \\ Independent researcher, Kazakhstan
}

\begin{abstract}
This article examines the key aspects of bank customer loyalty. In modern conditions of market competition, in any stable company or financial institution, one of the main goals is to attract new customers and retain existing ones. Therefore, there is a need for the bank and all companies in general to develop a plan for building stable customer satisfaction, as well as build a path with the study of analysis, with drawbacks and possible losses, in order to have a stable loyalty program. When implementing this program, it will develop a range of marketing activities. This topic can show that the loyalty program is one of the key levers for attracting customers, which will primarily affect the profitability, income and performance of the bank as a whole. Thus, it can also be noted that in the future in any developed or developing country, this program will gain new momentum in the field of business and banking services.
\end{abstract}

Keywords: Loyalty, Bank, Financial Performance, Retail Banking

В условиях быстро растущей конкуренции, роста затрат на привлечение клиентов, такие понятия как « потребительская лояльность » и « уровень обслуживания » становятся неразделимыми понятиями.

На данном этапе и возникает вопрос о лояльности персонала. Если сотрудники как минимум, влияют на процессную сторону, то отношенческая сторона обслуживания прежде всего будет зависеть от персонала. Сотрудник, который абсолютно лояльный к своему банку, не объединяется в критике работы своей организации, он всегда стремится показывать ее с лучшей стороны, более вовлечен в продукт, соответственно потребитель, чувствуя такую приверженность и искренность со стороны ее работников по отношению к данному продукту и данной компании, получает как минимум положительные эмоции и как максимум принимает быстрое решение о покупке, рекомендует компанию, менеджера своим знакомым и самое главное, становится более лояльным.

Актуальность исследования взаимосвязи между лояльностью сотрудников и потребителями в банковской сфере обусловлена несколькими причинами как с теоретической, так и с практической точки зрения. С практической точки зрения, можно привести следующие аргументы. Во-первых, кредитный рынок можно 
охарактеризовать как высококонкурентный, особенно в развитых странах. Сам кредитный рынок быстро обретает новые обороты. Во-вторых, на основе вышесказанного следует акцентировать внимание на том, что данный рынок находится на стадии быстрого развития, в связи с его насыщением. Соответственно, банки постепенно переходят от стратегии активного привлечения клиента, на стратегию удержания.

На Западе данная тема начала активно изучаться еще с конца 80 -х годов прошлого века, однако в странах СНГ (Казахстан, Кыргызстан, Узбекистан) можно найти лишь отдельные исследования, посвященные либо лояльности персонала, либо лояльности заемщиков.

В связи с этим, существенным достижением работы, претендующей на научную новизну, является анализ, систематизация теоретических и практических взглядов, эмпирических исследований зарубежных и казахстанских авторов о влиянии лояльности персонала на лояльность клиентов для кредитного рынка Казахстана в частности.

Качество обслуживания серьезно влияет на конкурентоспособность услуг и банка, а значит, и на стабильность доходов и прибыль. Мировой опыт и практика показывают, что инвестиции в совершенствование качества обслуживания клиентов рассматриваются как интенсивное развитие и влияют на стабильность роста доходов банка.

Наличие лояльности, т. е. благоприятного отношения потребителей к данной организации и ее продуктам, служит основой для получения стабильного объема продаж, что, в свою очередь, является стратегическим показателем успешности организации. Под лояльностью клиентов к банку понимается положительное отношение потребителей ко всему, что касается деятельности данной организации: оказываемым банковским услугам, персоналу, имиджу, исходящей от банка информации, рекламным обращениям, символике и т. п. 
Лояльными можно назвать тех потребителей, которые в течение длительного времени взаимодействуют с организацией и совершают при этом повторные покупки. Основой для лояльности служит позитивный опыт, который клиент приобрел в процессе пользования продуктом, услугой.

Важную роль играет также степень напряженности коммуникаций между потребителями банковских услуг и сотрудниками организации.

Поэтому определение приоритетных мер и необходимых корректирующих воздействий, а также дополнительных мероприятий в целях улучшения качества обслуживания в банке является первостепенным фактором его успешного существования на рынке. Уровень лояльности потребителей банковских услуг, степень их удовлетворенности качеством обслуживания в коммерческом банке предполагается определить с помощью маркетингового исследования.

На сегодняшний день наблюдается нечеткое разграничение терминов «потребительская лояльность» и «лояльность бренду». Они получили свое развитие в разное время и в рамках разных концепций: термин «лояльность бренду» был введен в употребление в начале 20-х годов в США и получил свое развитие в рамках концепции брэндинга, а термин «потребительская лояльность» стал активно развиваться в 80-е годы в рамках концепции маркетинга взаимоотношений.

Удовлетворенность клиента зависит от качества работы всей компании, тогда как программу лояльности следует рассматривать как одну из альтернатив маркетинговым коммуникациям. Однако, недооценивать роль программ лояльности также не следует, поэтому в современных условиях для большинства компаний программы лояльности для клиентов необходимо дополнять программами по повышению потребительской удовлетворенности.

\section{References}

1. Andreev A.G. Lojal'nyj potrebitel'. Marketing i marketingovye issledovanija, [Loyal consumer. Marketing and marketing research ] — 2003. — № 2.

2. L. S. Shajahovskaja, Lojal'nost' - kak filosofija [Loyalty as a philosophy]. 2003 
3. Ju. L. Bugorskaja, Ot stimulirovanija sbyta $-k$ povysheniju lojal'nosti potrebitelej: programmy pooshhrenija [From Sales Promotion to Customer Loyalty: Incentive Programs] // Marketingovye kommunikacii. - 2003 g. - № 3

\title{
Translation of the Title, Abstract and References to the Author's Language
}

\section{Повышение лояльности клиентов в сфере розничных банковских услуг и влияние на финансовые результаты деятельности банка}

\author{
Асель Исхакова \\ Независимый исследователь, Казахстан
}

В данной статье разбираются ключевые аспекты клиентской лояльности банка. В современных условиях рыночной конкуренции, в любой стабильной компании или финансовом институте, одной из основных целей является- привлечение новых клиентов и удержание уже имеющихся. Поэтому есть необходимость для банка и всех компаний в целом, разработать план по постройке стабильной удовлетворенности клиентов, так же выстроить путь с изучением анализа, с недостатками и возможными потерями, чтобы иметь стабильную программу лояльности. При внедрении данной программы, оно будет развивать комплекс маркетинговых мероприятий. Данная тема, может показать, что программа лояльности является одним из ключевых рычагов для привлечения клиентов, что в первую очередь повлияют на прибыльность, на доход и на показатели банка в целом. Тем самым можно так же отметить, что в будущем в любой развитой или в развивающейся стране, данная программа будет обретать новые обороты в сфере бизнеса и банковского обслуживания.

\section{Литература}

1. Андреев А.Г. Лояльный потребитель. Маркетинг и маркетинговые исследования, -2003 г. - № 2.

2. Л. С. Шаяховская, Лояльность - как философия 2003 г

3. Ю. Л. Бугорская, От стимулирования сбыта - к повышению лояльности потребителей: программы поощрения // Маркетинговые коммуникации. - 2003 г. - № 3 